\title{
Numerical Taxonomy of Photosynthetic Rhizobia Nodulating Aeschynomene Species
}

\author{
JAGDISH K. LADHA* AND ROLANDO B. SO \\ Soil Microbiology, Division of Soil \& Water Sciences, The International Rice Research Institute, \\ 1099 Manila, Philippines
}

\begin{abstract}
Fifty-two strains of photosynthetic rhizobia isolated from stem and root nodules of Aeschynomene afraspera, Aeschynomene denticulata, Aeschynomene evenia, Aeschynomene indica, Aeschynomene nilotica, Aeschynomene pratensis, Aeschynomene rudis, Aeschynomene schemperi, and Aeschynomene sensitiva were compared with reference rhizobial strains representing Rhizobium, Bradyrhizobium, and Azorhizobium species by performing a multivariate statistical analysis of 150 phenotypic characteristics. Eight phena, some of which contained subphena, were identified. Aeschynomene rhizobia which synthesize bacteriochlorophyll were grouped in phenon 6, which contained three subphena, while nonphotosynthetic Aeschynomene rhizobia were grouped in phena 1 and 2 . Our results indicate that the photosynthetic rhizobia nodulating Aeschynomene species belong to a phenon (phenon 6) that is separate from the genera Bradyrhizobium (phena 1 to 5), Azorhizobium (phenon 7), and Rhizobium (phenon 8).
\end{abstract}

The following four genera of stem- and root-nodulating rhizobia are listed in the Index of the Bacterial and Yeast Nomenclatural Changes (15): Rhizobium, which includes six species (Rhizobium leguminosarum, Rhizobium meliloti, Rhizobium loti, Rhizobium galegae, Rhizobium tropici, and Rhizobium huakuii); Bradyrhizobium, which includes one species (Bradyrhizobium japonicum); Azorhizobium, which includes one species (Azorhizobium caulinodans); and Sinorhizobium, which includes fast-growing rhizobia that nodulate soybeans and contains two species (Sinorhizobium fredii and Sinorhizobium xinjiangensis).

Recently, several rhizobial isolates which produce bacteriochlorophyll have been isolated from stem nodules of members of the genus Aeschynomene (4, 14). At least 21 Aeschynomene species are known to express the trait of nodule formation on aboveground plant parts (13). Flood tolerance combined with fast growth and high $\mathrm{N}_{2}$-fixing activity make many Aeschynomene species suitable for use as green manure in lowland rice cultivation (13). An initial attempt to characterize rhizobial isolates obtained from Aeschynomene stem nodules led to the conclusion that it would be difficult to include these rhizobial isolates in one of the four previously described genera $(1,2,4)$, especially since some of the isolates had the unique ability to synthesize bacteriochlorophyll inside as well as outside nodules. Therefore, a new genus and species, "Photorhizobium thompsonianum," was proposed for the bacteria which are stem symbionts of members of the genus Aeschynomene and produce bacteriochlorophyll (4).

Young et al. (28) recently proposed that photosynthetic strain BTAi 1, which was isolated from stem nodules on Aeschynomene indica, may belong to the Bradyrhizobium cluster after they examined the DNA sequence of a 260-bp 16S rRNA gene fragment. The results of these authors suggested that designation of the genus "Photorhizobium" may be premature or unwarranted. However, since the

${ }^{*}$ Corresponding author. Mailing address: Soil Microbiology, Division of Soil \& Water Sciences, The International Rice Research Institute, P. O. Box 933, Manila, Philippines. Phone: (63-2) 818 1926. Fax: (63-2) 818-2087. Electronic mail address: INTERNET: IN\% “JLADHA@CGNET.COM".
International Committee on Systematic Bacteriology has recommended that taxonomic designations should be based on examination of multiple phenotypes and phylogenetic traits of a large number of independent isolates (6), we initiated a large-scale study to characterize rhizobial strains nodulating Aeschynomene species. In this study, 68 photosynthetic and nonphotosynthetic rhizobium strains belonging to several species that nodulate stems and roots of members of the genus Aeschynomene were characterized. About 150 cultural, morphological, and physiological traits were used to study the phenotypic relationships among different groups of our isolates and several reference strains belonging to the genera Rhizobium, Bradyrhizobium, and Azorhizobium.

\section{MATERIALS AND METHODS}

Bacterial strains. The strains which we used and their sources are listed in Table 1. Rhizobia were isolated from nine species of the genus Aeschynomene grown at different locations in the Philippines by using the method described by Vincent (23). Nonphotosynthetic rhizobia were isolated from root and stem nodules of Aeschynomene afraspera collected in Ubon, Thailand, and from Aeschynomene fluminensis grown in the Philippines. Root-nodulating strains from Crotalaria juncea grown in a sugar cane field in India. Root- and stem-nodulating strains were collected from Sesbania rostrata grown at four different locations (Laguna, Nueva Ecija, Cotabato, and Quezon) having different soil characteristics in the Philippines.

Growth media. All strains of Rhizobium and Bradyrhizobium species were grown and maintained on mannitol-yeast extract agar. Photosynthetic rhizobia and Azorhizobium caulinodans cultures were grown and maintained on tryptone-glucose-yeast extract agar containing $5 \mathrm{~g}$ of tryptone per liter, $1 \mathrm{~g}$ of glucose per liter, and $2.5 \mathrm{~g}$ of yeast extract per liter. "Protaminobacter ruber" NCIB 2879 and Pseudomonas radiora IAM 12089 were grown in medium containing (per liter) $200 \mathrm{ml}$ of potato extract, $10 \mathrm{~g}$ of Polypeptone, $10 \mathrm{~g}$ of glucose, and $2.5 \mathrm{~g}$ of yeast extract. All strains were grown at $30^{\circ} \mathrm{C}$ and stored on slants or in lyophilized form.

Cultural characteristics. Rhizobia in the logarithmic growth phase were harvested, washed, and resuspended in 
TABLE 1. Origins and hosts of the bacterial strains used.

\begin{tabular}{|c|c|c|c|c|c|}
\hline $\operatorname{Strain}(\mathrm{s})^{a}$ & Host & Origin $^{b}$ & Source ${ }^{a}$ & Phenon & Subphenon \\
\hline \multicolumn{6}{|l|}{ Photosynthetic rhizobia } \\
\hline IRBG 2 & Aeschynomene afraspera & Laguna & IRRI & 6 & $\mathbf{A}$ \\
\hline ORS 322 & Aeschynomene afraspera & Senegal & ORSTOM & 6 & $\mathbf{B}$ \\
\hline IRBG 231 & Aeschynomene denticulata & Laguna & IRRI & 6 & B \\
\hline IRBG 232, IRBG 233, IRBG 234, IRBG 275 & Aeschynomene evenia & Laguna & IRRI & 6 & $\mathbf{B}$ \\
\hline IRBG 91, IRBG 92, IRBG 276, IRBG 277 & Aeschynomene indica & Laguna & IRRI & 6 & B \\
\hline BTAi 1 & Aeschynomene indica & United States & BTI & 6 & $\mathrm{C}$ \\
\hline IRBG 210, IRBG 223, IRBG 224, IRBG 241 & Aeschynomene indica & Iloilo & IRRI & 6 & $\mathbf{B}$ \\
\hline $\begin{array}{l}\text { IRBG 278, IRBG 279, IRBG } 280 \text {, IRBG } 281 \text {, } \\
\text { IRBG 230, IRBG 282, IRBG } 283\end{array}$ & Aeschynomene nilotica & Laguna & IRRI & 6 & A \\
\hline $\begin{array}{l}\text { IRBG 126, IRBG 127, IRBG 284, IRBG 285, } \\
\text { IRBG 286, IRBG } 287\end{array}$ & Aeschynomene pratensis & Laguna & IRRI & 6 & B \\
\hline IRBG 123, IRBG 124, IRBG 125, IRBG 228 & Aeschynomene pratensis & Iloilo & IRRI & 6 & B \\
\hline IRBG 288 , IRBG 289 & Aeschynomene rudis & Laguna & IRRI & 6 & $\overline{\mathbf{B}}$ \\
\hline IRBG 249, IRBG 250, IRBG 251 & Aeschynomene schimperi & Laguna & IRRI & 6 & B \\
\hline $\begin{array}{l}\text { IRBG 121, IRBG 127, IRBG 290, IRBG 291, } \\
\text { IRBG 292, IRBG 293, IRBG 294, IRBG } \\
\text { 296, IRBG } 297\end{array}$ & Aeschynomene sensitiva & Laguna & IRRI & 6 & $\mathrm{C}$ \\
\hline $\begin{array}{l}\text { IRBG 114, IRBG 115, IRBG 116, IRBG 117, } \\
\text { IRBG 119, IRBG 118, IRBG } 120\end{array}$ & Aeschynomene sensitiva & Iloilo & IRRI & 6 & $\mathrm{C}$ \\
\hline \multicolumn{6}{|l|}{ Azorhizobium spp. } \\
\hline IRBG 31, IRBG 32 & Sesbania rostrata & Cotabato & IRRI & 7 & \\
\hline IRBG 8, IRBG 16 & Sesbania rostrata & Laguna & IRRI & 7 & \\
\hline IRBG 21 & Sesbania rostrata & Nueva Ecija & IRRI & 7 & \\
\hline ORS 571 & Sesbania rostrata & Senegal & ORSTOM & 7 & \\
\hline IRBG 43, IRBG 44, IRBG 45 & Sesbania rostrata & Quezon & IRRI & 7 & \\
\hline \multicolumn{6}{|l|}{ Bradyrhizobium spp. } \\
\hline $\begin{array}{l}\text { IRBG 251, IRBG 252, IRBG 253, IRBG 274, } \\
\text { IRBG 298, IRBG 299, IRBG } 300\end{array}$ & Aeschynomene afraspera & Thailand & IRRI & 1 & \\
\hline $\begin{array}{l}\text { IRBG 270, IRBG 271, IRBG 272, IRBG 273, } \\
\text { IRBG 301, IRBG 302, IRBG } 303\end{array}$ & Aeschynomene fluminensis & Maahas & IRRI & 2 & \\
\hline $\begin{array}{l}\text { IRBG 304, IRBG 305, IRBG 306, IRBG 307, } \\
\text { IRBG 308, IRBG 309, IRBG 310, IRBG } \\
\text { 311, IRBG } 312\end{array}$ & Crotalaria juncea & India & IRRI & 2 & \\
\hline JIR 33, NIAES 3127 & Glycine $\max$ & Japan & IB & 3 & \\
\hline TAL 379 , TAL 397 & Glycine $\max$ & United States & NifTAL & 3 & \\
\hline A1017 & Glycine max & Japan & IB & 4 & \\
\hline CB 1809 & Glycine max & $?$ & & 4 & \\
\hline TAL 102 & Glycine $\max$ & United States & NifTAL & 4 & \\
\hline TAL 1033 & Indigofera arrecta & United States & NifTAL & 3 & \\
\hline TAL 1037 & Indigofera brevicalyx & United States & NifTAL & 3 & \\
\hline TAL 289 & Indigofera endecaphylla & United States & NifTAL & 3 & \\
\hline TAL 760 , TAL 761 & Indigofera hirsuta & United States & NifTAL & 5 & \\
\hline TAL 290 , TAL 350 & Indigofera suffruticosa & United States & NifTAL & 4 & \\
\hline TAL 759, TAL 1038 & Indigofera sp. & United States & NifTAL & 4 & \\
\hline TAL 835 & Macrotyloma africanum & United States & NifTAL & 4 & \\
\hline $325 \mathrm{~B}$ & Macrotyloma sp. & United States & NifTAL & 4 & \\
\hline TAL 420 , TAL 441 & Vigna radiata & United States & NifTAL & 4 & \\
\hline TAL 169 & Vigna radiata & United States & NifTAL & 3 & \\
\hline $32 \mathrm{H} 1$ & Vigna unguiculata & $?$ & & 4 & \\
\hline IRC 256 & Vigna unguiculata & India & ICRISAT & 5 & \\
\hline IRC 279 & Vigna unguiculata & United States & BTI & 4 & \\
\hline TAL 209 & Vigna unguiculata & United States & NifTAL & 3 & \\
\hline \multicolumn{6}{|l|}{ Rhizobium spp. } \\
\hline TAL 1436R, TAL 1436S & Acacia farnesiana & United States & NifTAL & 8 & A \\
\hline IC 3038 , IC 3100 , IC 3509 & Cajanus cajan & India & ICRISAT & 8 & B \\
\hline TAL 624 & Cajanus cajan & United States & NifTAL & 8 & B \\
\hline TAL 1768 & Gliciridia sepium & United States & NifTAL & 8 & B \\
\hline TAL 634 & Lathyrus hirsutus & United States & NifTAL & 8 & B \\
\hline TAL 638 & Lens culinaris & United States & NifTAL & 8 & B \\
\hline TAL 1145 & Leucaena leucocephala & United States & NifTAL & 8 & B \\
\hline TAL 1372, TAL 380 & Medicago sativa & United States & NifTAL & 8 & $\mathbf{A}$ \\
\hline TAL 1797, TAL 1383 & Phaseolus vulgaris & United States & NifTAL & 8 & C \\
\hline TAL 353 & Sesbania grandiflora & United States & NifTAL & 8 & B \\
\hline TAL 1123 & Sesbania macrocarpa & United States & NifTAL & 8 & A \\
\hline TAL 674 & Sesbania rostrata & United States & NifTAL & 8 & A \\
\hline IC 3071 , IC 3073 & Sesbania sp. & India & ICRISAT & 8 & B \\
\hline TAL 1113 , TAL 1115 & Sesbania sp. & United States & NifTAL & 8 & B \\
\hline
\end{tabular}


TABLE 1-Continued.

\begin{tabular}{|c|c|c|c|c|c|}
\hline Strain $(s)^{a}$ & Host & Origin $^{b}$ & Source $^{a}$ & Phenon & Subphenon \\
\hline TAL 382 & Trifolium semipilosum & United States & NifTAL & 8 & B \\
\hline 45 & Trifolium sp. & Philippines & BIOTECH & 8 & A \\
\hline \multicolumn{6}{|l|}{ Photosynthetic nonrhizobia } \\
\hline Pseudomonas radiora IAM 12089 & & Japan & IAM & & \\
\hline Protaminobacter ruber NCIB 1933 & & Japan & SUT & & \\
\hline
\end{tabular}

a IRBG, The International Rice Research Institute Bacterial Germplasm, The International Rice Research Institute, Los Baños, Philippines; ATCC, American Type Culture Collection, Rockville, Md.; BIOTECH, National Institutes of Applied Microbiology and Biotechnology, UPLB, University of the Philippines at Los Baños, Los Baños, Philippines; BTI, Boyce Thompson Research Institute, New York, N.Y.; IAM, Institute of Applied Microbiology, The University of Tokyo, Tokyo, Japan; IB, Ibaraki University, Department of Agricultural Chemistry, Ibaraki-ken, Japan; ICRISAT, International Centre for Research in Semi-Arid Tropics, Patancheru, India; IRRI, The International Rice Research Institute, Los Baños, Philippines; NCIB, National Collection of Industrial Bacteria, Torry Research Station, Aberdeen, Scotland; NifTAL, Nitrogen Fixation in Tropical Agricultural Legumes, University of Hawaii, Paia; ORSTOM, Institut Francais de Recherche Scientifique Pour le Developpement en Cooperation, Paris, France; SUT, Department of Applied Science, Science University of Tokyo, Tokyo, Japan.

${ }^{b}$ All locations are in the Philippines unless indicated otherwise.

$0.1 \mathrm{M}$ phosphate buffer. Cell suspensions (approximately $10^{15}$ cells per ml) were placed into individual wells of multiwell plates, and different test media were added by using a multipoint inoculator (Mast Laboratories, Ltd., Merseyside, United Kingdom). Loopfuls of cell suspensions were used to inoculate test media prepared in tubes. Cultures were incubated at $30 \pm 1^{\circ} \mathrm{C}$ in the dark unless otherwise stated. Reactions were scored after 1, 2, and 7 days of incubation. Media devoid of test substrates were used as negative controls and were incubated along with the test media.

Morphological characteristics. Strains grown on mannitolyeast extract agar for 7 days were examined for cell and colony morphology and for such characteristics as color, consistency, presence or absence of gummy substances, Gram reaction, presence of spores, and motility by using the methods described in the Manual of Methods for General Microbiology (18).

Antibiotic resistance tests. The agar diffusion disc method and a Sensi-Disc eight-place dispenser (BBL, Cockeysville, Md.) were used for antibiotic resistance tests. Zones of inhibition were measured for each disc, and the organisms were scored as resistant (inhibition zone, 0 to $2 \mathrm{~mm}$ ) or susceptible (inhibition zone, $>2 \mathrm{~mm}$ ). The following antibiotics and amounts per disc were used: amikacin, $10 \mu \mathrm{g}$; ampicillin, $10 \mu \mathrm{g}$; bacitracin, $10 \mathrm{U}$; carbenicillin, $100 \mu \mathrm{g}$; cephalothin, $30 \mu \mathrm{g}$; cefoperazone, $75 \mu \mathrm{g}$; cefuroxine, $30 \mu \mathrm{g}$; chlortetracycline, $30 \mu \mathrm{g}$; ciprofloxacin, $5 \mu \mathrm{g}$; cloxacillin, 1 $\mu \mathrm{g}$; doxycycline, $30 \mu \mathrm{g}$; gentamicin, $10 \mu \mathrm{g}$; imipenen, $10 \mu \mathrm{g}$; kanamycin, $30 \mu \mathrm{g}$; lincomycin, $2 \mu \mathrm{g}$; methicillin, $5 \mu \mathrm{g}$; minocycline, $30 \mu \mathrm{g}$; nafcillin, $1 \mu \mathrm{g}$; nalidixic acid, $30 \mu \mathrm{g}$; netilmicin, $30 \mu \mathrm{g}$, nitrofurantoin, $100 \mu \mathrm{g}$; novobiocin, $30 \mu \mathrm{g}$; oxacillin, $1 \mu \mathrm{g}$; penicillin, $100 \mu \mathrm{g}$, polymyxin $\mathrm{B}, 100 \mathrm{U}$; streptomycin, $10 \mu \mathrm{g}$; sulfisoxazole, $250 \mu \mathrm{g}$; tobramycin, 10 $\mu \mathrm{g}$; and vancomycin, $30 \mu \mathrm{g}$.

Acetylene reduction assays. Acetylene reduction (nitrogen fixation) activity was determined on basal $\mathrm{N}_{2}$-free semisolid agar by using the method described by Watanabe et al. (24).

Bacteriochlorophyll determination. Rhizobia were grown on $0.1 \times$ tryptone-glucose-yeast extract agar with a light-dark cycle for 7 days. The cells were harvested and suspended in $25 \%$ bovine serum albumin (BSA), and the cells were then used for in vivo absorption spectrum determinations. Fresh root and stem nodules were macerated with a homogenizer in acetone-methanol $(7: 2, \mathrm{vol} / \mathrm{vol})$, and the suspension was centrifuged for $15 \mathrm{~min}$ at $5,000 \mathrm{rpm}$ to separate the solvent extract from the plant debris. The absorption spectra of cell suspensions in $25 \%$ BSA and nodule extracts in the acetone- methanol solution were determined by using a scanning spectrophotometer (Shimadzu Co., Inc., Kyoto, Japan) at wavelengths of 300 to $900 \mathrm{~nm}$.

Utilization of sole carbon sources. Utilization of carbon compounds as sole carbon sources was tested by using a basal medium supplemented with different carbon sources at a final concentration of $0.2 \%$ (wt/vol). Bromothymol blue at a concentration of $0.0025 \%$ was used as the $\mathrm{pH}$ indicator. The $\mathrm{pH}$ of each medium was adjusted to $7.0 \pm 1$ by using sterile $1 \mathrm{M} \mathrm{NaOH}$ or $1 \mathrm{~N} \mathrm{HCl}$ after the carbon source was added. The following carbon sources were tested: acetate, adonitol, L-arabinose, cellobiose, citrate, dextrin, dulcitol, $\mathrm{D}$-fructose, fumarate, galactose, gluconate, glucose, glycerol, inulin, meso-inositol, lactose, trehalose, malonate, maltose, D-mannose, D-melibiose, pyruvate, L-rhamnose, $\mathrm{D}$-ribose, saccharic acid, sorbose, sucrose, trehalose, xylitol, and xylose. All of the carbon compounds were filter sterilized before they were added to the basal medium. Basal medium supplemented with mannitol was used as the positive control, and basal medium without mannitol was used as the negative control. Changes in the $\mathrm{pH}$ values of the media were recorded after 7 days of incubation.

Utilization of amino acids as sole nitrogen sources. Utilization of amino acids as sole nitrogen sources was tested by using a basal medium in which $\mathrm{NH}_{2} \mathrm{SO}_{4}$ was replaced by the following amino acids: L-alanine, L-arginine, L-asparagine, L-glycine, L-lysine, L-methionine, L-ornithine, DL-phenylalanine, DL-threonine, DL-tryptophan, and L-tyrosine. Basal medium containing $\mathrm{NH}_{2} \mathrm{SO}_{4}$ was used as the positive control, and basal medium lacking a nitrogen source was used as the negative control. All amino acids were prepared as stock solutions and were filter sterilized before they were added to basal medium to obtain a final concentration of $10 \mathrm{mM}$.

Miscellaneous other tests. The oxidase test was performed with cytochrome oxidase test paper (Nissui Seiyaku, Tokyo, Japan). Catalase activity was determined by gas production after addition of a $3 \%$ hydrogen peroxide solution. Tests for tolerance for different $\mathrm{NaCl}$ concentrations $(0.5,1,2$, and $3 \%$ ), different $\mathrm{pH}$ levels $(4,5,6,7,8$, and 9$)$, and different temperatures $\left(20,30\right.$, and $\left.45^{\circ} \mathrm{C}\right)$ were performed on mannitol-yeast extract medium. The reaction to litmus milk was examined by using Difco litmus milk medium. Tests for gelatinase activity, starch hydrolysis, nitrate reduction, denitrification, DNase activity, and penicillinase activity were carried out by using the methods described in the Manual of Methods for General Microbiology (18).

Nodulation tests. Nodulation by all of the rhizobium strains isolated in this study was verified by examining nodulation in 
the homologous host plants, using the methods described by Vincent (23). Legumes were grown in test tubes containing Jensen $\mathrm{N}_{2}$-free agar medium (23). Stem inoculation tests were performed with 4-week-old plants by applying gum arabic-based cell suspensions with sterile brushes. The plants were incubated at $30^{\circ} \mathrm{C}$ during the day and at $25^{\circ} \mathrm{C}$ during the night in a light- and humidity-controlled growth chamber. The presence or absence of nodules and the appearance of the plants were recorded after 2 weeks of incubation.

Numerical analyses. All tests were performed in duplicate, and the data were recorded in binary code. A cluster analysis of 150 phenotypic variables was performed by using singlelinkage, average-linkage, and Ward minimum variance methods, using the Clustan software package (25) and an IBM mainframe computer. The unweighted pair group method with averages was chosen instead of the single-linkage, complete-linkage, or Ward method, because the best separation was obtained with this method (19).

\section{RESULTS}

A numerical taxonomic analysis of Aeschynomene rhizobia showed that all of the photosynthetic rhizobia could be included in one phenon (phenon 6) if a similarity level of $86 \%$ was used; three subphena were formed at a similarity level of $89 \%$ (Fig. 1). Slowly growing rhizobia formed the first five phena, and phena 1 and 2 contained the nonphotosynthetic Aeschynomene rhizobia. Phenon 7 included all of the Azorhizobium strains, while phenon 8, which was composed of three subphena, included all fast-growing rhizobia. The important characteristics of each phenon are described below.

Phenon 1 contained seven strains of rhizobia isolated from Aeschynomene afraspera grown in a rice field in Ubon, Thailand. Six strains formed a group at a similarity level of $88 \%$, while strain IRBG 251 clustered with the other strains in the phenon at a similarity level of $83 \%$. All of the strains formed effective root and stem nodules on Aeschynomene afraspera but not on other Aeschynomene species (data not shown) and were devoid of bacteriochlorophyll when they were grown under the conditions used for photosynthetic rhizobia. The characteristics shared by the members of phenon 1 are shown in Table 2. Strain IRBG 251 is phenotypically distinct from the other rhizobia in the phenon and could be differentiated from the other strains on the basis of utilization of pyruvate, arginine, tryptophan, and tyrosine.

Phenon 2 consisted of eight rhizobial strains isolated from Aeschynomene fluminensis and eight strains isolated from Crotalaria juncea. The rhizobia isolated from Aeschynomene fluminensis exhibited a very high degree of similarity $(97 \%)$, while the strains isolated from Crotalaria juncea clustered at a similarity level of $94 \%$. The overall level of similarity between the strains isolated from Aeschynomene fluminensis and the strains isolated from Crotalaria juncea was $84 \%$. A total of 97 phenotypic characteristics (including negative characteristics) were shared by the rhizobia belonging to this phenon. The following key characteristics differentiated the strains isolated from Aeschynomene fluminensis and the strains isolated from Crotalaria juncea: utilization of acetate, fumarate, and pyruvate as energy sources; and resistance to gentamicin and polymyxin B but not to doxycycline, minocycline, netilmicin, and novobiocin.

Phenon 3 included rhizobial strains isolated from Glycine max (two strains), Indigofera spp. (three strains), and Vigna radiata (one strain). Variable carbon compound utilization reactions were observed for the members of this phenon. All of the strains assimilated all of the amino acids tested except glycine and tryptophan. Litmus milk remained unchanged even after 7 days of incubation. The resistance to antibiotics varied, but all strains were susceptible to amikacin, imipenen, minocycline, and streptomycin.

Phenon 4 contained 15 rhizobial strains isolated from Glycine max (5 strains), Vigna unguiculata (2 strains), $V$. radiata (2 strains), Indigofera sp. (2 strains), Indigofera suffruticosa (2 strains), Macrotyloma africanum (1 strain), and Macrotyloma sp. (1 strain). Hup ${ }^{+}$B. japonicum A1017 and NIAES 3127 and Hup ${ }^{-} B$. japonicum JIR 33 were included in this phenon. Utilization of carbon compounds varied among the strains. Only a few of the strains did not utilize glycine and tryptophan. All strains were resistant to most of the antibiotics tested; the exceptions were amikacin, gentamicin, imipenen, kanamycin, netilmicin, minocycline, and streptomycin. None of the strains turned litmus milk alkaline, but $13 \%$ of the strains exhibited an acid reaction and a serum zone after 7 days of incubation. Nitrate was reduced to nitrite by $60 \%$ of the strains, but no strain could further reduce nitrite to gaseous nitrous oxide. Strain $32 \mathrm{H} 1$ and two strains isolated from Indigofera spp. fixed $\mathrm{N}_{2}$ under free-living conditions.

Phenon 5 contained 2 rhizobial strains isolated from $I n$ digofera hirsuta and 2 strains isolated from $V$. unguiculata; these strains clustered at a similarity level of $82 \%$. The carbon utilization patterns of these strains varied widely, while all strains utilized 4 of the 11 amino acids tested (alanine, arginine, asparagine, and ornithine) as carbon and nitrogen sources. All of the strains exhibited multiple antibiotic resistance (Table 2 ).

Phenon 6 contained 54 photosynthetic rhizobial strains isolated from stem nodules on eight species belonging to the genus Aeschynomene; these strains formed a cluster at a similarity level of $84 \%$. All of the strains except ORS 322 and BTAi 1 were isolated in this study. The 54 strains could be subdivided into subphena $6 \mathrm{~A}, 6 \mathrm{~B}$, and $6 \mathrm{C}$. Strain BTAi 1 , an isolate obtained from the United States, (22), clearly differed from Philippine isolates obtained from Aeschynomene indica and other strains belonging to subphena 6A and 6B (Fig. 1). The most interesting characteristic of this group was the ability of the rhizobia to synthesize bacteriochlorophyll inside stem nodules under symbiotic and free-living conditions (Fig. 2). All strains belonging to this group had the ability to grow and fix $\mathrm{N}_{2}$ in the absence of combined $\mathrm{N}$. The asymbiotic nitrogenase activity observed in the strains belonging to this group has been reported by other workers $(1$, $2,4,5)$.

Subphenon $6 \mathrm{~A}$ contained seven rhizobial strains isolated from Aeschynomene nilotica and 1 strain isolated from Aeschynomene afraspera. The similarity level for all of the strains isolated from Aeschynomene nilotica was very high $(96 \%)$, while the level of similarity between the strains isolated from Aeschynomene nilotica and the strains isolated from Aeschynomene afraspera was $91 \%$. Key characteristics that differentiated the strains isolated from the two Aeschynomene species included utilization of inulin as a carbon source, acidification of glycerol, alkalinization of lactose and xylose, and resistance to vancomycin (Table 3).

Subphenon 6B contained rhizobial strains isolated from several species belonging to the genus Aeschynomene (4 strains isolated from Aeschynomene evenia, 10 strains isolated from Aeschynomene pratensis, 8 strains isolated from three accessions of Aeschynomene indica, 2 strains isolated from Aeschynomene schemperi, 2 strains isolated from 


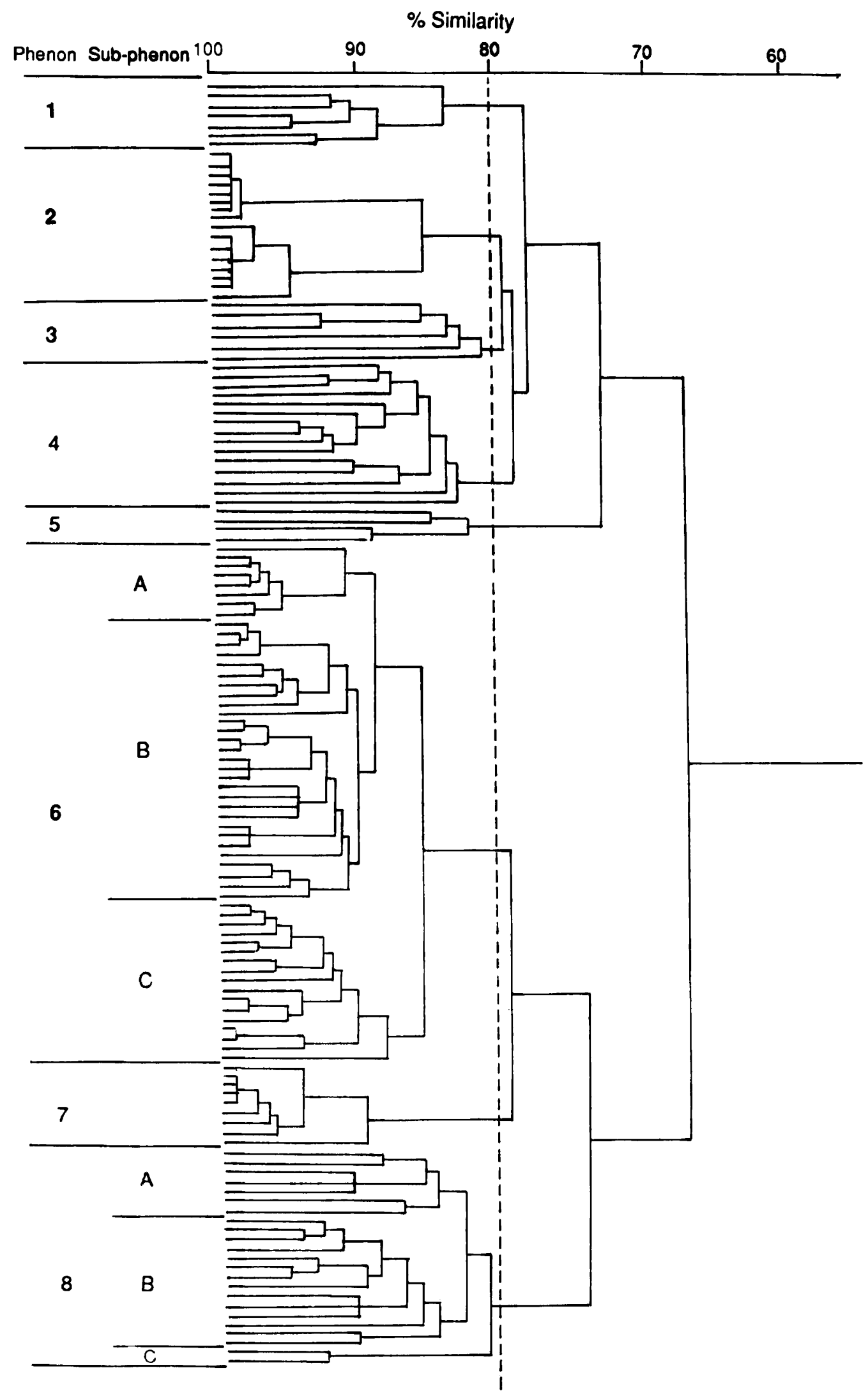

FIG. 1. Dendrogram showing phenotypic relationships of rhizobia isolated from Aeschynomene species and other species of stem and root nodule bacteria. Phena 1, 2, and 6 contained rhizobia isolated from Aeschynomene species, and phenon 6 contained photosynthetic rhizobia. 
TABLE 2. Characteristics of thizobia belonging to different phena ${ }^{a}$

\begin{tabular}{|c|c|c|c|c|c|c|c|c|c|c|c|c|}
\hline \multirow[b]{3}{*}{ Characteristic } & \multicolumn{12}{|c|}{$\%$ of strains positive } \\
\hline & \multirow[b]{2}{*}{$\begin{array}{c}\text { Phenon } \\
1 \\
(n=7)^{b}\end{array}$} & \multirow[b]{2}{*}{$\begin{array}{c}\text { Phenon } \\
2 \\
(n=16)\end{array}$} & \multirow[b]{2}{*}{$\begin{array}{l}\text { Phenon } \\
\quad 3 \\
(n=6)\end{array}$} & \multirow[b]{2}{*}{$\begin{array}{c}\text { Phenon } \\
4 \\
(n=15)\end{array}$} & \multirow[b]{2}{*}{$\begin{array}{l}\text { Phenon } \\
5 \\
(n=4)\end{array}$} & \multicolumn{3}{|c|}{ Phenon 6} & \multirow[b]{2}{*}{$\begin{array}{l}\text { Phenon } \\
\quad 7 \\
(n=9)\end{array}$} & \multicolumn{3}{|c|}{ Phenon 8} \\
\hline & & & & & & $\begin{array}{c}\text { Sub- } \\
\text { phenon } \\
\text { A } \\
(n=8)\end{array}$ & $\begin{array}{c}\text { Sub- } \\
\text { phenon } \\
\text { B } \\
(n=29)\end{array}$ & $\begin{array}{c}\text { Sub- } \\
\text { phenon } \\
\text { C } \\
(n=17)\end{array}$ & & $\begin{array}{c}\text { Sub- } \\
\text { phenon } \\
\text { A } \\
(n=7)\end{array}$ & $\begin{array}{c}\text { Sub- } \\
\text { phenon } \\
\text { B } \\
(n=14)\end{array}$ & $\begin{array}{c}\text { Sub- } \\
\text { phenon } \\
\text { C } \\
(n=2)\end{array}$ \\
\hline Gummy soft & 100 & 50 & 83 & 73 & 100 & 0 & 0 & 0 & 0 & 86 & 100 & 100 \\
\hline Gummy hard & 0 & 0 & 17 & 13 & 0 & 0 & 0 & 0 & 0 & 0 & 0 & 0 \\
\hline Not gummy & 0 & 50 & 0 & 13 & 0 & 88 & 100 & 100 & 100 & 14 & 0 & 0 \\
\hline Penicillinase & 100 & 100 & 100 & 73 & 75 & 100 & 100 & 100 & 100 & 86 & 71 & 50 \\
\hline \multicolumn{13}{|l|}{ Litmus milk reaction } \\
\hline Alkaline & 57 & 56 & 0 & 0 & 75 & 0 & 14 & 6 & 89 & 14 & 36 & 0 \\
\hline Acid & 0 & 0 & 0 & 13 & 25 & 0 & 0 & 0 & 11 & 0 & 21 & 0 \\
\hline Neutral & 43 & 44 & 100 & 73 & 0 & 100 & 86 & 94 & 0 & 86 & 21 & 50 \\
\hline Serum formed & 0 & 0 & 17 & 13 & 50 & 0 & 0 & $\mathbf{0}$ & 67 & 29 & 50 & 0 \\
\hline Gelatinase & 0 & 63 & 50 & 67 & 50 & 0 & 0 & 0 & 0 & 29 & 36 & 100 \\
\hline DNase & 29 & 0 & 0 & 0 & 0 & 0 & 0 & 0 & 0 & 0 & 0 & 50 \\
\hline Starch hydrolysis & 0 & 0 & 0 & 0 & 0 & 0 & 0 & 0 & 0 & 0 & 0 & 0 \\
\hline Nitrogen fixation & 0 & 0 & 0 & 44 & 0 & 100 & 100 & 100 & 100 & 0 & 0 & 0 \\
\hline Bacteriochlorophyll & 0 & 0 & 0 & 0 & 0 & 100 & 100 & 100 & 0 & 0 & 0 & 0 \\
\hline Hayne's medium & 100 & 0 & 33 & 33 & 25 & 75 & 59 & 47 & 100 & 43 & 21 & 0 \\
\hline Alpha-ketolactose & 0 & 0 & 17 & 7 & 0 & 0 & 0 & 0 & 0 & 0 & 14 & 0 \\
\hline Denitrification & 14 & 0 & 0 & 0 & 0 & 0 & 38 & 18 & 0 & 0 & 0 & 0 \\
\hline Nitrate reduction & 86 & 50 & 33 & 60 & 50 & 88 & 100 & 82 & 0 & 43 & 43 & 0 \\
\hline Growth at: & & & & & & & & & & & & \\
\hline pH 4 & 100 & 100 & 17 & 20 & 50 & 13 & 0 & 6 & 100 & 14 & 64 & 0 \\
\hline pH 5 & 100 & 100 & 67 & 93 & 100 & 100 & 93 & 100 & 100 & 57 & 93 & 50 \\
\hline pH 8 & 100 & 100 & 50 & 53 & 75 & 100 & 93 & 65 & 100 & 71 & 79 & 50 \\
\hline $\mathrm{pH} 9$ & 100 & 100 & 33 & 20 & 25 & 13 & 3 & 6 & 100 & 43 & 71 & 0 \\
\hline Growth in the presence o & & & & & & & & & & & & \\
\hline $0.5 \% \mathrm{NaCl}$ & 100 & 100 & 67 & 73 & 75 & 100 & 100 & 100 & 100 & 100 & 86 & 100 \\
\hline $3 \% \mathrm{NaCl}$ & 0 & 0 & 33 & 13 & 0 & 0 & 0 & 0 & 11 & 29 & 14 & 50 \\
\hline Utilization (as a carbon $\mathbf{s}$ & & & & & & & & & & & & \\
\hline Acetate & 0 & 44 & 0 & 33 & 50 & 88 & 100 & 94 & 100 & 100 & 71 & 50 \\
\hline Adonitol & 100 & 94 & 100 & 60 & 50 & 88 & 100 & 100 & 100 & 100 & 100 & 0 \\
\hline Arabinose & 71 & 94 & 100 & 73 & 75 & 100 & 83 & 100 & 0 & 100 & 100 & 0 \\
\hline Cellobiose & 71 & 94 & 67 & 20 & 50 & 100 & 0 & 100 & 0 & 100 & 100 & 50 \\
\hline Citrate & 0 & 0 & 17 & 33 & 50 & 100 & 79 & 82 & 44 & 43 & 57 & 50 \\
\hline Dextrin & 43 & 94 & 83 & 13 & 50 & 13 & 0 & 94 & 100 & 86 & 93 & 0 \\
\hline Dulcitol & 57 & 44 & 83 & 20 & 25 & 13 & 10 & 100 & 0 & 86 & 93 & 50 \\
\hline Fructose & 57 & 50 & 83 & 73 & 100 & 100 & 93 & 100 & 100 & 86 & 100 & 50 \\
\hline Fumarate & 14 & 44 & 33 & 40 & 25 & 0 & 100 & 100 & 100 & 100 & 86 & 0 \\
\hline Galactose & 86 & 94 & 100 & 53 & 50 & 100 & 100 & 100 & 0 & 100 & 100 & 50 \\
\hline Gluconate & 100 & 94 & 83 & 53 & 100 & 100 & 100 & 100 & 100 & 29 & 100 & 100 \\
\hline Glucose & 71 & 94 & 100 & 73 & 75 & 100 & 100 & 100 & 100 & 100 & 100 & 100 \\
\hline Glycerol & 100 & 94 & 100 & 73 & 75 & 100 & 100 & 100 & 100 & 100 & 100 & 0 \\
\hline Inulin & 0 & 94 & 83 & 0 & 25 & 88 & 0 & 0 & 0 & 0 & 7 & 0 \\
\hline Inositol & 100 & 94 & 50 & 7 & 25 & 0 & 0 & 100 & 0 & 100 & 100 & 100 \\
\hline Lactose & 43 & 94 & 100 & 20 & 75 & 0 & 14 & 94 & 100 & 100 & 100 & 100 \\
\hline Malate & 43 & $\mathbf{0}$ & 17 & 60 & 50 & 100 & 100 & 100 & 100 & 100 & 79 & 100 \\
\hline Malonate & 100 & 0 & 17 & 7 & 0 & 0 & 52 & 94 & 100 & 86 & 86 & 50 \\
\hline Maltose & 71 & 94 & 83 & 27 & 25 & 100 & 0 & 100 & 0 & 100 & 100 & 50 \\
\hline Mannose & 43 & 94 & 100 & 60 & 75 & 100 & 100 & 100 & 0 & 100 & 100 & 50 \\
\hline Melibiose & 71 & 13 & 33 & 40 & 50 & 0 & 0 & 6 & 100 & 100 & 100 & 50 \\
\hline Pyruvate & 14 & 44 & 33 & 47 & 50 & 0 & 100 & 6 & 100 & 100 & 93 & 100 \\
\hline Rhamnose & 57 & 94 & 50 & 40 & 50 & 88 & 14 & 6 & 100 & 100 & 100 & 0 \\
\hline Ribose & 100 & 94 & 83 & 93 & 100 & 88 & 90 & 100 & 100 & 100 & 100 & 0 \\
\hline Saccharic acid & 57 & 50 & 33 & 67 & 100 & 88 & 100 & 100 & 100 & 14 & 36 & 0 \\
\hline Sorbose & 57 & 94 & 17 & 40 & 50 & 0 & 0 & 100 & 100 & 57 & 79 & 0 \\
\hline Sucrose & 71 & 6 & 0 & 13 & 25 & 0 & 21 & 94 & 0 & 100 & 100 & 0 \\
\hline Trehalose & 57 & 94 & 33 & 33 & 25 & 88 & 24 & 100 & 100 & 100 & 100 & 50 \\
\hline Xylitol & 57 & 94 & 17 & 13 & 25 & 0 & 0 & 100 & 0 & 100 & 100 & 50 \\
\hline Xylose & 13 & 94 & 83 & 80 & 100 & 100 & 97 & 100 & 100 & 100 & 100 & 0 \\
\hline Alkalinization on: & & & & & & & & & & & & \\
\hline Arabinose & 0 & 0 & 33 & 20 & 25 & 0 & 0 & 24 & 100 & 0 & 0 & 0 \\
\hline Fructose & 14 & 50 & 33 & 20 & 25 & 0 & 0 & 0 & 100 & 0 & 7 & 0 \\
\hline Galactose & 71 & 44 & 83 & 33 & 25 & 0 & 0 & 0 & 0 & 0 & 7 & 0 \\
\hline
\end{tabular}




\begin{tabular}{|c|c|c|c|c|c|c|c|c|c|c|c|c|}
\hline \multirow[b]{3}{*}{ Characteristic } & \multicolumn{12}{|c|}{$\%$ of strains positive } \\
\hline & \multirow[b]{2}{*}{$\begin{array}{c}\text { Phenon } \\
1 \\
(n=7)^{b}\end{array}$} & \multirow[b]{2}{*}{$\begin{array}{c}\text { Phenon } \\
2 \\
(n=16)\end{array}$} & \multirow[b]{2}{*}{$\begin{array}{c}\text { Phenon } \\
3 \\
(n=6)\end{array}$} & \multirow[b]{2}{*}{$\begin{array}{c}\text { Phenon } \\
4 \\
(n=15)\end{array}$} & \multirow[b]{2}{*}{$\begin{array}{c}\text { Phenon } \\
5 \\
(n=4)\end{array}$} & \multicolumn{3}{|c|}{ Phenon 6} & \multirow[b]{2}{*}{$\begin{array}{c}\text { Phenon } \\
7 \\
(n=9)\end{array}$} & \multicolumn{3}{|c|}{ Phenon 8} \\
\hline & & & & & & $\begin{array}{c}\text { Sub- } \\
\text { phenon } \\
\text { A } \\
(n=8)\end{array}$ & $\begin{array}{c}\text { Sub- } \\
\text { phenon } \\
\text { B } \\
(n=29)\end{array}$ & $\begin{array}{c}\begin{array}{c}\text { Sub- } \\
\text { phenon } \\
\text { C } \\
(n=17)\end{array}\end{array}$ & & $\begin{array}{c}\text { Sub- } \\
\text { phenon } \\
\text { A } \\
(n=7)\end{array}$ & $\begin{array}{c}\begin{array}{c}\text { Sub- } \\
\text { phenon } \\
\text { B } \\
(n=14)\end{array}\end{array}$ & $\begin{array}{c}\text { Sub- } \\
\text { phenon } \\
\text { C } \\
(n=2)\end{array}$ \\
\hline Gluconate & 100 & 50 & 50 & 13 & 25 & 100 & 0 & 100 & 0 & 0 & 7 & 0 \\
\hline Glucose & 86 & 0 & 83 & 33 & 75 & 0 & 3 & 94 & 100 & 0 & 0 & 0 \\
\hline Glycerol & 86 & 0 & 33 & 33 & 25 & 0 & 0 & 94 & 0 & 0 & 0 & 0 \\
\hline Lactose & 14 & 44 & 83 & 20 & 75 & 88 & 0 & 0 & 100 & 14 & 7 & 0 \\
\hline Maltose & 71 & 0 & 17 & 33 & 25 & 100 & 97 & 100 & 0 & 57 & 14 & 0 \\
\hline Rhamnose & 57 & 50 & 50 & 33 & 50 & 0 & 0 & 6 & 100 & 0 & 0 & 0 \\
\hline Sucrose & 14 & 6 & 0 & 7 & 0 & 0 & 0 & 0 & 0 & 0 & 0 & 0 \\
\hline Xylose & 0 & 94 & 33 & 27 & 50 & 88 & 0 & 0 & 0 & 0 & 0 & 0 \\
\hline \multicolumn{13}{|l|}{ Acidification on: } \\
\hline Arabinose & 0 & 44 & 17 & 7 & 0 & 0 & 3 & 41 & 0 & 43 & 86 & 0 \\
\hline Fructose & 0 & 0 & 17 & 0 . & 0 & 0 & 0 & 0 & 0 & 29 & 21 & 0 \\
\hline Galactose & 0 & 0 & 0 & 7 & 25 & 88 & 0 & 0 & 0 & 57 & 79 & 0 \\
\hline Glucose & 0 & 50 & 0 & 0 & 0 & 100 & 0 & 6 & 0 & 57 & 86 & 0 \\
\hline Glycerol & 14 & 94 & 50 & 7 & 0 & 88 & 0 & 6 & 0 & 29 & 71 & 0 \\
\hline Lactose & 0 & 0 & 0 & 0 & 0 & 0 & 0 & 0 & 0 & 29 & 29 & 0 \\
\hline Rhamnose & 0 & 44 & 0 & 0 & 0 & 0 & 0 & 0 & 0 & 14 & 43 & 0 \\
\hline Sucrose & 0 & 0 & 0 & 0 & $\mathbf{0}$ & 0 & 0 & 0 & 0 & 29 & 57 & 0 \\
\hline Xylose & 0 & $\mathbf{0}$ & 33 & 0 & 0 & 13 & 14 & 100 & 0 & 29 & 57 & $\mathbf{0}$ \\
\hline $\begin{array}{l}\text { Utilization (as a carbon and } \\
\text { nitrogen source) of: }\end{array}$ & & & & & & & & & & & & \\
\hline Alanine & 100 & 100 & 100 & 100 & 100 & 100 & 100 & 100 & 100 & 71 & 93 & 100 \\
\hline Arginine & 14 & 100 & 100 & 87 & 100 & 100 & 100 & 100 & 100 & 57 & 93 & 100 \\
\hline Asparagine & 100 & 100 & 100 & 93 & 100 & 100 & 100 & 100 & 100 & 100 & 100 & 100 \\
\hline Glycine & 86 & 0 & 17 & 7 & 0 & 0 & 0 & 0 & 0 & 43 & 43 & 100 \\
\hline Lysine & 100 & 56 & 100 & 80 & 75 & 100 & 100 & 100 & 100 & 71 & 71 & 100 \\
\hline Methionine & 100 & 100 & 100 & 87 & 75 & 100 & 66 & 24 & 100 & 57 & 86 & 100 \\
\hline Ornithine & 100 & 100 & 100 & 93 & 100 & 100 & 100 & 94 & 0 & 86 & 100 & 100 \\
\hline Phenylalanine & 100 & 100 & 100 & 100 & 75 & 100 & 66 & 24 & 0 & 57 & 64 & 100 \\
\hline Threonine & 100 & 100 & 100 & 100 & 75 & 100 & 66 & 24 & 100 & 43 & 64 & 100 \\
\hline Tryptophan & 14 & 100 & 50 & 27 & 25 & 100 & 66 & 24 & 100 & 43 & 50 & 100 \\
\hline Tyrosine & 14 & 100 & 100 & 80 & 50 & 100 & 66 & 24 & 0 & 86 & 57 & 100 \\
\hline Resistance to: & & & & & & & & & & & & \\
\hline Amikacin $(10 \mu \mathrm{g} / \mathrm{disc})$ & 100 & 0 & 0 & 0 & 0 & 0 & 3 & 0 & 0 & 0 & 0 & 0 \\
\hline Ampicillin $(10 \mu \mathrm{g} / \mathrm{disc})$ & 100 & 100 & 67 & 80 & 75 & 100 & 90 & 100 & 100 & 57 & 21 & 0 \\
\hline Bacitracin (10 U/disc) & 100 & 100 & 83 & 80 & 75 & 100 & 90 & 94 & 100 & 57 & 43 & 100 \\
\hline Carbenicillin $(100 \mu \mathrm{g} / \mathrm{disc})$ & 100 & 100 & 17 & 73 & 25 & 100 & 66 & 88 & 0 & 14 & 0 & 0 \\
\hline Cephalothin $(30 \mu \mathrm{g} / \mathrm{disc})$ & 100 & 100 & 50 & 93 & 75 & 25 & 7 & 6 & 0 & 29 & 0 & 0 \\
\hline Cefoperazone $(75 \mu \mathrm{g} / \mathrm{disc})$ & 100 & 100 & 100 & 100 & 100 & 100 & 66 & 59 & 100 & 71 & 36 & 0 \\
\hline Cefuroxine $(30 \mu \mathrm{g} / \mathrm{disc})$ & 100 & 100 & 17 & 40 & 75 & 63 & 21 & 0 & 100 & 57 & 29 & $\mathbf{0}$ \\
\hline Chlortetracycline $(30 \mu \mathrm{g} / \mathrm{disc})$ & 100 & 0 & 50 & 73 & 100 & 0 & 0 & 0 & 0 & 0 & 36 & 0 \\
\hline Ciprofloxacin $(5 \mu \mathrm{g} /$ disc $)$ & 100 & 100 & 83 & 100 & 100 & 38 & 48 & 53 & 100 & 14 & 7 & 0 \\
\hline Cloxacillin $(1 \mu \mathrm{g} /$ disc $)$ & 100 & 100 & 83 & 100 & 100 & 100 & 97 & 94 & 100 & 100 & 79 & 100 \\
\hline Doxycycline $(30 \mu \mathrm{g} / \mathrm{disc})$ & 100 & 56 & 100 & 100 & 100 & 0 & 0 & 0 & 0 & 0 & 7 & 0 \\
\hline Gentamicin $(10 \mu \mathrm{g} / \mathrm{disc})$ & 100 & 44 & 33 & 13 & 50 & 0 & 69 & 41 & 0 & 0 & 0 & 0 \\
\hline Imipenen $(10 \mu \mathrm{g} / \mathrm{disc})$ & 0 & 0 & 0 & 7 & 0 & 0 & 0 & 0 & 100 & 0 & 0 & 0 \\
\hline Kanamycin $(30 \mu \mathrm{g} / \mathrm{disc})$ & 0 & 0 & 17 & 13 & 50 & 0 & 3 & 0 & 0 & 0 & 0 & 0 \\
\hline Lincomycin $(2 \mu \mathrm{g} / \mathrm{disc})$ & 100 & 100 & 100 & 100 & 100 & 100 & 97 & 100 & 100 & 100 & 100 & 100 \\
\hline Methicillin $(5 \mu \mathrm{g} / \mathrm{disc})$ & 100 & 100 & 100 & 100 & 100 & 100 & 100 & 100 & 100 & 100 & 86 & 100 \\
\hline Minocycline $(30 \mu \mathrm{g} /$ disc $)$ & 0 & 56 & 0 & 20 & 25 & 0 & 0 & 0 & 0 & 0 & 0 & 0 \\
\hline Nafcillin $(1 \mu \mathrm{g} /$ disc $)$ & 100 & 100 & 100 & 100 & 100 & 100 & 97 & 100 & 100 & 100 & 100 & 100 \\
\hline Nalidixic acid $(30 \mu \mathrm{g} / \mathrm{disc})$ & 100 & 100 & 100 & 93 & 100 & 13 & 14 & 29 & 100 & 100 & 64 & 0 \\
\hline Netilmicin $(30 \mu \mathrm{g} /$ disc $)$ & 0 & 56 & 17 & 7 & 50 & 0 & 7 & 35 & 0 & 0 & 0 & 0 \\
\hline Nitrofurantoin $(100 \mu \mathrm{g} / \mathrm{disc})$ & 100 & 100 & 100 & 100 & 100 & 100 & 100 & 100 & 0 & 100 & 71 & 0 \\
\hline Novobiocin $(30 \mu \mathrm{g} / \mathrm{disc})$ & 100 & 56 & 33 & 67 & 100 & 0 & 17 & 0 & 100 & 71 & 50 & 0 \\
\hline Oxacillin $(1 \mu \mathrm{g} / \mathrm{disc})$ & 100 & 100 & 100 & 100 & 100 & 100 & 100 & 100 & 100 & 100 & 100 & 100 \\
\hline Penicillin (100 U/disc) & 100 & 100 & 83 & 87 & 100 & 100 & 93 & 100 & 100 & 71 & 36 & 100 \\
\hline Polymyxin B (100 U/disc) & 100 & 44 & 100 & 100 & 100 & 100 & 97 & 100 & 0 & 14 & 43 & 0 \\
\hline Streptomycin $(10 \mu \mathrm{g} / \mathrm{disc})$ & 100 & 0 & 0 & 20 & 25 & 0 & 3 & 24 & 0 & 14 & 36 & 0 \\
\hline Sulfisoxazole $(250 \mu \mathrm{g} / \mathrm{disc})$ & 100 & 100 & 83 & 100 & 100 & 100 & 100 & 100 & 100 & 100 & 100 & 100 \\
\hline Tobramycin $(10 \mu \mathrm{g} / \mathrm{disc})$ & 100 & 100 & 50 & 87 & 100 & 0 & 0 & 0 & 0 & 0 & 7 & 0 \\
\hline Vancomycin $(30 \mu \mathrm{g} / \mathrm{disc})$ & 100 & 100 & 100 & 100 & 100 & 88 & 76 & 59 & 100 & 0 & 7 & 0 \\
\hline
\end{tabular}

a Phena 1 and 2 contained nonphototrophic rhizobia isolated from Aeschynomene species, phenon 6 contained all of the phototrophic rhizobial strains isolated from Aeschynomene species, phenon 7 contained all of the Azorhizobium strains, and phenon 8 contained all of the fast-growing Rhizobium strains. All of the strains examined were gram negative, motile, aerobic, and positive for cytochrome oxidase and catalase, did not produce clots in litmus milk, did not hydrolyze starch, did not tolerate 5 to $10 \% \mathrm{NaCl}$, did not grow at 39 to $45^{\circ} \mathrm{C}$, and grew at 20 to $30^{\circ} \mathrm{C}$ at pH 6 to 7 .

$b$ is the number of strains examined. 


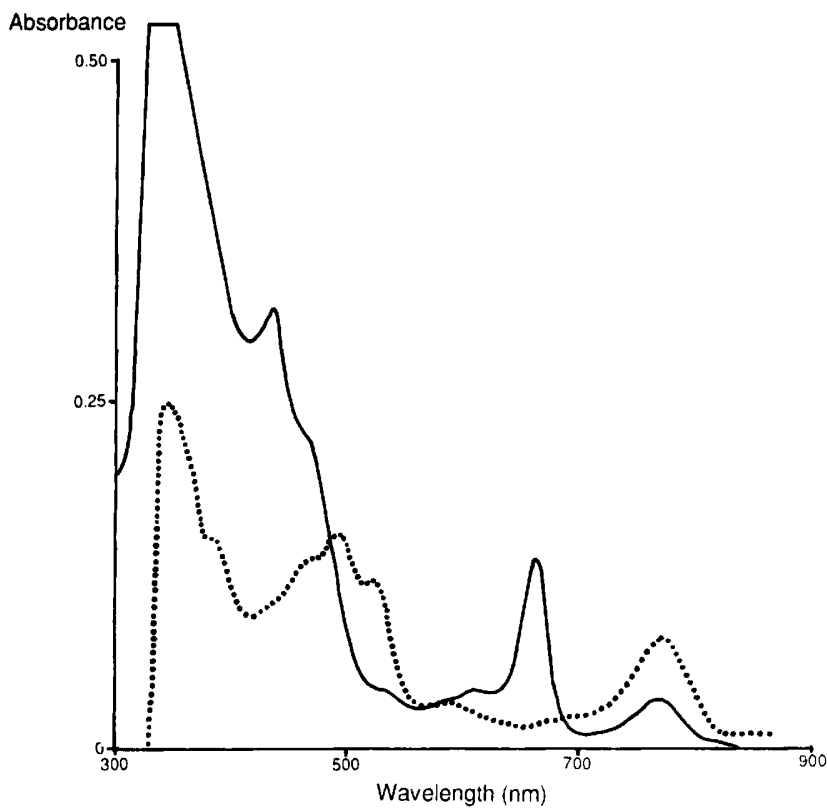

FIG. 2. Absorption spectra for photosynthetic rhizobia (dotted line) in 25\% BSA and Aeschynomene afraspera stem nodule extracts in acetone-methanol $(7: 2, \mathrm{vol} / \mathrm{vol}$ ) (solid line), showing the positions of chlorophyll and bacterochlorophyll $a$ at wavelengths of 660 and $770 \mathrm{~nm}$, respectively.

Aeschynomene rudis, 1 strain isolated from Aeschynomene denticulata, and 1 strain isolated from Aeschynomene afraspera [ORS 322]). Most of the strains utilized the majority of the carbon compounds tested. Only the strains isolated from Aeschynomene pratensis utilized trehalose. None of the rhizobial strains isolated from Aeschynomene evenia utilized most of the amino acids as nitrogen sources. Of the 29 antibiotics tested, only 5 were found to be inhibitory. Nitrate was reduced, but denitrification was observed only in strains isolated from Aeschynomene evenia and in a few strains isolated from Aeschynomene pratensis.

Subphenon $6 \mathrm{C}$ contained 16 rhizobial strains isolated from Aeschynomene sensitiva and 1 strain isolated from Aeschynomene indica (strain BTAi 1). The rhizobia isolated from Aeschynomene sensitiva were homogenous (similarity level, 90\%). A total of 93 phenotypic characteristics (including negative characteristics) were shared by all of the strains in the subphenon. Strains isolated from Aeschynomene sensitiva differed from BTAi 1 in the following characteristics: utilization of acetate, lactose, and malonate; and alkalinization of glucose and glycerol. Arginine was the only amino acid utilized by strains isolated from Aeschynomene sensitiva strains but not by BTAi 1 . All strains isolated from Aeschynomene sensitiva were resistant to bacitracin and carbenicillin, in contrast to BTAi 1.

The phenotypic groups of stem-nodulating rhizobia isolated from Aeschynomene species are somewhat similar to the cross-inoculation groups. The strains belonging to crossinoculation groups 2 and 3 of Alazard et al. (1) were similar to the strains belonging to phenotypic subphena $6 \mathrm{~A}$ and $6 \mathrm{~B}$ (Fig. 1). However, strains isolated from Aeschynomene indica and Aeschynomene sensitiva, which formed a separate phenotypic group (subphenon $6 \mathrm{C}$ ), also belonged to cross-inoculation group 2 (1).

Phenon 7 was a cluster that contained closely related organisms and formed at a similarity level of $88 \%$. All of the phenon 7 strains except strain ORS 571 were isolated from stem and root nodules of Sesbania rostrata. Strain ORS 571, the type strain of Azorhizobium caulinodans, was obtained from Institut Francais de Recherche Scientifique Pour le Developpement en Cooperation. This group was homogeneous, and its members shared 129 phenotypic characteristics (including negative characteristics). All of the strains fixed $\mathrm{N}_{2}$ ex planta, but they did not produce bacteriochlorophyll inside or outside the nodules.

Phenon 8 contained 23 rhizobial strains and was divided into three subphena, subphena $8 \mathrm{~A}, 8 \mathrm{~B}$, and $8 \mathrm{C}$. The strains grew rapidly on mannitol-yeast extract agar, were motile, did not produce alkali in sugar media, and utilized a wide range of carbon compounds. These characteristics are similar to those generally found in members of the genus Rhizobium (11).

Subphenon 8A contained six rhizobial strains (two variant strains isolated from Acacia famesiana, two strains isolated from Medicago sativa, 1 strain isolated from $S$. rostrata, and 1 strain isolated from Sesbania macrocarpa. Strain TAL 674 , which supposedly was isolated from $S$. rostrata, appeared to be either mislabeled or a contaminant. These strains were obtained from the Nitrogen Fixation in Tropical Agricultural Legumes culture collection. The strains belonging to this subphenon utilized a wide range of carbon compounds and acidified most of them. Aspartate was the only amino acid used as a nitrogen source. All of the strains were resistant to cloxacillin, lincomycin, methicillin, nafcillin, nalidixic, nitroforantoin, oxacillin, and sulfisoxazole; $43 \%$ of the strains reduced nitrate, but none could denitrify.

Subphenon 8B was large and diverse; it contained strains isolated from Cajanus cajan (four strains), Sesbania sp. (five strains), Gliciridia sepium (one strain), Leucaena leucocephala (one strain), Lens culinaris (one strain), Lathyrus hirsutus (one strain), and Trifolium semipilosum (one strain). These strains used a wide range of carbon compounds as energy sources and were resistant to lincomycin, nafcillin, oxacillin, and sulfisoxazole (Table 2).

Subphenon $8 \mathrm{C}$ contained two rhizobial strains isolated from Phaseolus vulgaris, and these strains exhibited a similarity level of $90 \%$. Strains belonging to this subphenon could be differentiated from other strains on the basis of their ability to utilize various carbon sources.

\section{DISCUSSION}

The phenotypic character-based numerical taxonomy method used in this study clearly showed that all photosynthetic rhizobial strains can be grouped together at a similarity level of $86 \%$ and cluster with other well-defined groups of rhizobia only at low levels of similarity. This suggests that the photosynthetic rhizobia are members of a new genus, but this conclusion is contradicted by the results of Young et al. (28), which were based on a 16S rRNA gene sequence analysis and suggested that one of the photosynthetic isolates obtained from Aeschynomene indica clusters with the $B$. japonicum group. Moreover, the results of our 16S rRNA gene sequence and fatty acid profile analyses of a number of photosynthetic isolates obtained from Aeschynomene species also suggest that these organisms should be included in the Bradyrhizobium cluster (20), although clearly not in the three previously described $B$. japonicum DNA homology groups distinguished by Hollis et al. (9). The apparent discrepancy between these results and the observations of 
TABLE 3. Characteristics that differentiate the nonphotosynthetic and photosynthetic rhizobia isolated from Aeschynomene species

\begin{tabular}{|c|c|c|c|c|c|c|c|c|c|c|c|c|}
\hline \multirow{3}{*}{ Characteristic } & \multicolumn{12}{|c|}{ Reaction of: } \\
\hline & \multicolumn{10}{|c|}{ Photosynthetic rhizobia isolated from: } & \multicolumn{2}{|c|}{ Nonphotosynthetic } \\
\hline & $\begin{array}{c}\text { A. } \\
\text { afraspera } \\
(n=2)^{a}\end{array}$ & $\begin{array}{c}A . \\
\text { denticulata } \\
(n=1)\end{array}$ & $\begin{array}{c}\text { A. } \\
\text { evenia } \\
(n=4)\end{array}$ & $\begin{array}{c}A . \\
\text { indica } \\
(n=8)\end{array}$ & $\begin{array}{c}A . \\
\text { indica } \\
(n=1)^{b}\end{array}$ & $\begin{array}{c}\text { A. } \\
\text { nilotica } \\
(n=7)\end{array}$ & $\begin{array}{c}A . \\
\text { pratensis } \\
(n=10)\end{array}$ & $\begin{array}{c}\text { A. } \\
\text { rudis } \\
(n=2)\end{array}$ & $\begin{array}{c}A . \\
\text { schemperi } \\
(n=3)\end{array}$ & $\begin{array}{c}A . \\
\text { sensitiva } \\
(n=16)\end{array}$ & $\begin{array}{c}A . \\
\text { afraspera } \\
(n=5)\end{array}$ & $\begin{array}{c}A . \\
\text { fluminensis } \\
(n=7)\end{array}$ \\
\hline Nitrogen fixation & $t^{c}$ & + & + & + & + & + & + & + & + & + & - & - \\
\hline $\begin{array}{l}\text { Bacteriochlorophyll } a \\
\text { Litmus milk reaction }\end{array}$ & + & + & + & + & + & + & + & + & + & + & - & - \\
\hline Alkaline & D & - & - & D & + & - & - & - & - & - & D & + \\
\hline Neutral & $\mathrm{D}$ & + & + & $\mathrm{D}$ & - & + & + & + & + & + & D & - \\
\hline \multicolumn{13}{|l|}{ Growth at: } \\
\hline $\mathrm{pH} 4$ & D & - & - & - & + & - & - & - & - & - & + & + \\
\hline pH 8 & & + & + & + & - & + & + & + & + & D & + & + \\
\hline pH 9 & D & - & D & - & - & - & - & - & - & - & + & + \\
\hline Denitrification & - & + & + & - & - & - & D & - & - & - & - & - \\
\hline \multicolumn{13}{|l|}{ Utilization of carbon sources } \\
\hline Acetate & $\mathrm{D}$ & + & + & + & - & + & + & + & + & + & - & + \\
\hline Adonitol & $\mathrm{D}$ & + & + & + & + & + & + & + & + & + & + & + \\
\hline Cellobiose & D & - & - & - & + & + & - & - & - & + & D & + \\
\hline Citrate & + & + & + & + & + & + & D & + & + & + & - & - \\
\hline Dextrin & D & - & - & - & - & - & - & - & - & + & D & + \\
\hline Dulcitol & $\mathrm{D}$ & - & - & - & + & - & D & - & - & + & D & + \\
\hline Fumarate & $\mathrm{D}$ & + & + & + & + & - & + & + & + & + & - & + \\
\hline Inositol & - & - & - & - & + & - & - & - & - & + & - & + \\
\hline Inulin & - & - & - & - & - & + & - & - & - & - & + & + \\
\hline Lactose & - & - & - & - & - & - & D & - & - & + & D & + \\
\hline Malate & + & + & + & + & + & + & + & + & + & + & D & - \\
\hline Malonate & - & + & D & D & - & - & - & + & + & + & + & - \\
\hline Maltose & D & - & - & - & + & + & - & - & - & + & D & + \\
\hline Pyruvate & D & + & + & + & + & - & + & + & + & - & - & + \\
\hline Rhamnose & D & - & - & D & + & + & - & - & - & - & D & + \\
\hline Ribose & D & + & + & D & + & + & + & + & + & + & + & + \\
\hline Sorbose & - & - & - & - & + & - & - & - & - & + & D & + \\
\hline Trehalose & $\mathrm{D}$ & - & - & - & + & + & + & - & - & + & D & + \\
\hline \multicolumn{13}{|l|}{ Acidification of carbon sources } \\
\hline Galactose & - & - & - & - & - & + & - & - & - & - & - & - \\
\hline Glucose & D & - & - & - & + & + & - & - & - & - & - & - \\
\hline Glycerol & - & - & - & - & + & + & - & - & - & - & - & + \\
\hline Rhamnose & - & - & - & - & - & - & - & - & - & - & - & + \\
\hline Xylose & $\mathrm{D}$ & - & - & - & + & - & $\mathrm{D}$ & - & - & + & - & - \\
\hline Alkalinazation of carbon sou & & & & & & & & & & & & \\
\hline Gluconate & D & - & - & - & + & + & - & - & - & + & + & - \\
\hline Glucose & - & - & - & - & - & - & - & - & $\mathrm{D}$ & + & + & - \\
\hline Glycerol & - & - & - & - & - & - & - & - & - & + & + & - \\
\hline Lactose & - & - & - & - & - & + & - & - & - & - & $\mathrm{D}$ & + \\
\hline Maltose & D & + & + & + & + & + & + & + & + & + & D & - \\
\hline Xylose & - & - & - & - & - & + & - & - & - & - & - & + \\
\hline $\begin{array}{l}\text { Utilization of amino acids as } \\
\mathbf{N} \text { sources }\end{array}$ & & & & & & & & & & & & \\
\hline Arginine & + & + & + & + & - & + & + & + & + & + & - & + \\
\hline Glycine & - & - & - & - & - & - & - & - & - & - & + & - \\
\hline Methionine & + & + & - & + & + & + & D & + & + & - & + & + \\
\hline Phenylalanine & + & + & - & + & + & + & D & + & + & - & + & + \\
\hline Threonine & + & + & - & + & + & + & $\mathrm{D}$ & + & + & - & + & + \\
\hline Tryptophan & + & + & - & + & + & + & $\mathrm{D}$ & + & + & - & - & + \\
\hline Tyrosine & + & + & - & + & + & + & $\mathrm{D}$ & + & + & - & - & + \\
\hline Resistance to antibiotics & & & & & & & & & & & & \\
\hline Amikacin $(10 \mu \mathrm{g})$ & - & - & - & - & - & - & - & - & - & - & + & - \\
\hline Ampicillin $(10 \mu \mathrm{g})$ & $\mathrm{D}$ & - & $\mathrm{D}$ & + & + & + & + & + & + & + & + & + \\
\hline Bacitracin (10 U) & + & + & + & + & - & + & + & + & - & + & + & + \\
\hline Carbenicillin $(100 \mu \mathrm{g})$ & $\mathrm{D}$ & - & D & D & - & + & + & D & + & + & + & + \\
\hline Cefoperazone $(75 \mu \mathrm{g})$ & + & - & - & D & + & + & + & - & + & D & + & + \\
\hline Cefuroxine $(30 \mu g)$ & - & - & D & D & - & D & - & - & + & & + & + \\
\hline Cephalothin $(30 \mu \mathrm{g})$ & - & - & - & D & + & $\mathrm{D}$ & - & - & - & - & + & + \\
\hline Chlortetracycline $(30 \mu \mathrm{g})$ & - & - & - & - & - & - & - & - & - & - & + & - \\
\hline Ciprofloxacin $(5 \mu \mathrm{g})$ & - & + & + & D & + & D & D & D & - & D & + & + \\
\hline Doxycycline $(30 \mu \mathrm{g})$ & - & - & - & - & - & - & - & - & - & - & + & - \\
\hline Gentamicin $(10 \mu \mathrm{g})$ & - & + & $\mathrm{D}$ & D & - & - & + & D & + & D & + & + \\
\hline Nalidixic acid $(30 \mu \mathrm{g})$ & - & - & $\mathrm{D}$ & $\mathrm{D}$ & + & - & + & - & - & D & + & + \\
\hline Netilmicin $(30 \mu \mathrm{g})$ & - & - & $\mathrm{D}$ & - & - & - & - & - & - & D & - & - \\
\hline Novobiocin $(30 \mu \mathrm{g})$ & - & - & $\mathrm{D}$ & - & - & - & - & - & + & - & + & - \\
\hline Streptomycin $(10 \mu \mathrm{g})$ & - & - & $\mathrm{D}$ & - & - & - & - & - & - & D & + & - \\
\hline Tobramycin $(10 \mu \mathrm{g})$ & - & - & - & - & - & - & - & - & - & - & + & + \\
\hline Vancomycin $(30 \mu \mathrm{g})$ & - & - & + & D & + & + & + & D & + & D & + & + \\
\hline
\end{tabular}

${ }^{a} n$ is the number of strains examined.

${ }^{b}$ Strain BTAi 1.

$c+, 80 \%$ or more of the strains are positive;,$- 80 \%$ or more of the strains are negative; $\mathrm{D}, 79 \%$ or fewer of the strains are negative. 
TABLE 4. Differential characteristics of aerobic and anaerobic photosynthetic bacteria ${ }^{a}$

\begin{tabular}{|c|c|c|c|c|c|}
\hline \multirow[b]{2}{*}{ Characteristic } & \multicolumn{3}{|c|}{ Aerobes } & \multicolumn{2}{|c|}{ Facultative anerobes } \\
\hline & Rhizobia & $\begin{array}{c}\text { Protaminobacter } \\
\text { ruber NCIB } \\
2879\end{array}$ & $\begin{array}{c}\text { Pseudomonas } \\
\text { radiora IAM } \\
12089\end{array}$ & $\begin{array}{l}\text { Rhodo- } \\
\text { pseudomoncs } \\
\text { palustris }\end{array}$ & $\begin{array}{l}\text { Rhodopseudomonas } \\
\text { gelatinosa }\end{array}$ \\
\hline Colony color & $\operatorname{Pink}^{b}$ & Pink & Pink & Red-brown & Yellow-brown \\
\hline Flagellation & Subpolar to polar & Polar & Polar & Subpolar & Subpolar \\
\hline Denitrification & $\mathrm{D}^{1}$ & - & - & & \\
\hline Nitrate reduction & + & - & + & & \\
\hline Penicillinase & + & + & - & + & + \\
\hline Anaerobiosis & - & - & - & + & + \\
\hline Gelatinase & - & - & - & + & $-c$ \\
\hline \multicolumn{6}{|l|}{ Bacteriochlorophyll production } \\
\hline Aerobic conditions & + & + & + & + & + \\
\hline Anaerobic conditions & - & - & - & + & + \\
\hline Continuous light & - & - & - & + & + \\
\hline Intermittent light & + & + & + & + & + \\
\hline Nitrogen fixation (free living) & + & - & - & + & + \\
\hline Growth at pH 5 & + & $+^{d}$ & + & + & \\
\hline \multicolumn{6}{|l|}{ Utilization (as a carbon source) of: } \\
\hline Arabinose & + & - & + & & \\
\hline Citrate & $\mathrm{D}$ & - & + & - & + \\
\hline Fructose & + & - & - & - & - \\
\hline Glucose & + & - & + & - & + \\
\hline Glycerol & + & $t^{e}$ & $t^{e}$ & $t^{c}$ & $--^{c}$ \\
\hline Malonate & $\mathrm{D}$ & - & - & $+^{c}$ & $+^{c}$ \\
\hline Mannose & + & $-{ }^{e}$ & $-^{e}$ & $-c$ & $+^{c}$ \\
\hline Pyruvate & D & - & - & + & + \\
\hline Succinate & + & - & - & - & D \\
\hline Trehalose & $\mathrm{D}$ & - & - & & \\
\hline \multicolumn{6}{|l|}{ Utilization (as a nitrogen source) of: } \\
\hline Alanine & + & & & $-^{c}$ & $t^{c}$ \\
\hline Asparagine & + & & & $-^{c}$ & $+^{c}$ \\
\hline \multicolumn{6}{|l|}{ Resistance to: } \\
\hline Amikacin $(10 \mu \mathrm{g})$ & - & + & - & & \\
\hline Carbenicillin $(100 \mu \mathrm{g})$ & $\mathrm{D}$ & - & - & & \\
\hline Cefoperazone $(75 \mu \mathrm{g})$ & $\mathrm{D}$ & - & - & & \\
\hline Cefuroxine $(30 \mu \mathrm{g})$ & - & + & - & & \\
\hline Ciprofloxacine $(30 \mu \mathrm{g})$ & D & + & + & & \\
\hline Cloxacillin $(1 \mu \mathrm{g})$ & + & + & + & & \\
\hline Gentamicin $(10 \mu \mathrm{g})$ & $\mathrm{D}$ & + & - & & \\
\hline Nalidixic acid $(30 \mu \mathrm{g})$ & - & + & + & & \\
\hline Netilmicin $(30 \mu \mathrm{g})$ & - & + & - & & \\
\hline Nitrofurantoin $(100 \mu \mathrm{g})$ & + & + & + & & \\
\hline Streptomycin $(10 \mu \mathrm{g})$ & - & + & - & & \\
\hline Sulfisoxazole $(250 \mu \mathrm{g})$ & - & + & + & & \\
\hline Tobramycin $(10 \mu \mathrm{g})$ & - & + & - & & \\
\hline Vancomycin $(30 \mu \mathrm{g})$ & $\mathrm{D}$ & + & + & & \\
\hline Nodulation on Aeschynomene spp. & $\mathrm{E}$ & $\mathbf{N}$ & $\mathbf{N}$ & $\mathbf{N}$ & $\mathbf{N}$ \\
\hline
\end{tabular}

$a+, 80 \%$ or more of the strains are positive;,$- 80 \%$ or more of the strains are negative; $\mathrm{D}, 79 \%$ or fewer of the strains are negative. All data were obtained in this study unless indicated otherwise.

${ }^{b}$ Color of colonies when the organisms are grown under intermittent light-dark illumination conditions.

${ }^{c}$ Data from reference $22 b$.

${ }^{d}$ Weak reaction.

${ }^{e}$ Data from reference 22 a.

${ }_{\mathrm{E}}$, nodulates the host legume; N, no nodules are formed on either the stems or the roots of Aeschynomene species.

Young et al. (28) may not be significant per se, but rather may be a reflection of the currently very preliminary and inconclusive taxonomy of the highly diverse genus Bradyrhizobium $(9,10,17,21)$. At this time, there are valid arguments for and against including photosynthetic rhizobia in the Bradyrhizobium cluster.

Previous studies of the phenotypic characteristics of strain BTAi1 isolated from stem nodules of Aeschynomene indica (22) and strain BICC 608 isolated from stem nodules of Aeschynomene aspera (3) led to the conclusion that these strains are examples of an intermediate type, having char- acteristics of members of both the fast-growing Rhizobium species and the slowly growing Bradyrhizobium species. The relatively fast growth of these strains, their ability to utilize disaccharides and tricarboxylic acid cycle intermediates (Table 2), the presence of a significant level of NADP-linked 6-phosphogluconate dehydrogenase activity, and the pentose phosphate pathway (3) are characteristics of Rhizobium strains. Characteristics such as subpolar flagellation, alkalinization of various compounds, reaction to litmus milk, and resistance to carbenicillin (Table 2) are characteristics of Bradyrhizobium strains. In addition, Chakrabarti et al. (3) 
found that strain BICC 608 exhibited DNA homology with representative Rhizobium and Bradyrhizobium strains.

On the basis of 16S rRNA oligonucleotide catalogs and the results of DNA-rRNA hybridization studies, it has been suggested that there is a close relationship between Bradyrhizobium strains and the facultatively anaerobic photosynthetic organism Rhodopseudomonas palustris $(8,10)$. Young et al. (28) have confirmed this observation and have also reported that the 16S rRNA gene sequences of strain BTAi 1 and Rhodopseudomonas palustris resemble Bradyrhizobium sequences. Jarvis et al. (10) have suggested that phylogenetic classifications should group the genera Bradyrhizobium and Rhodopseudomonas together. However, the aerobic photosynthetic bacteria, including the rhizobia, differ from the anaerobic photosynthetic bacteria in that the former synthesize bacteriochlorophyll only under aerobic conditions, whereas the latter require anaerobic conditions (7). The photosynthetic rhizobia produce the bacteriochlorophyll pigment during incubation under intermittent light-dark conditions but not during incubation under continuous illumination or continuous darkness (data not shown); however, this was not the case for marine bacteria (7) and other aerobic photosynthetic bacteria (16). The photosynthetic rhizobia also differ from other aerobic photosynthetic bacteria in that the former use a wide range of carbon compounds and are susceptible to many antibiotics (Table 4). In addition, the photosynthetic rhizobia are able to nodulate and form symbiotic associations with legumes (homologous plants), characteristics which are not found in nonrhizobial photosynthetic bacteria (Table 4). Phylogenetically, the aerobic photosynthetic bacteria, including the photosynthetic rhizobia, and the anaerobic anoxygenic phototrophs are closely related since they belong to the alpha purple groups $(26,27)$, but physiologically there are distinct differences between these groups.

In our dendrogram analysis we used a total of 150 characters, and these were weighted equally in accordance with the Adansonian principle. Besides the presence of bacteriochlorophyll, the following characteristics distinguish strains of photosynthetic rhizobia from strains of bradyrhizobia: gum production; dinitrogen-dependent growth and $\mathrm{N}_{2}$ fixation; utilization of acetate, citrate, and malate; alkalinization on maltose; susceptibility to cephalothin, doxycycline, and tobramycin; and resistance to nalidixic acid. The genus Bradyrhizobium is highly diverse $(9-11,17)$, and some of the diagnostic characteristics listed above are not completely unknown in this genus. The five phena representing Bradyrhizobium strains clustered at a much lower similarity level $(73 \%)$ than the three subphena in the group of photosynthetic rhizobia do.

Although until recently the genus Bradyrhizobium was thought to have only one species ( $B$. japonicum), the genus has been reported to be composed of at least three distinct subgroups $(9,17,21)$. Recently, on the basis of DNA homology data another species, Bradyrhizobium elkanii sp. nov., has been described (12). On the basis of phenotype characteristics, in this study we distinguished the photosynthetic rhizobia from members of the genera Bradyrhizobium, Rhizobium, and Azorhizobium at similarity levels of 73, 74, and $79 \%$, respectively. Determining whether the photosynthetic rhizobia should be assigned to a new genus or to the genus Bradyrhizobium as a new species will require further work.

\section{ACKNOWLEDGMENTS}

We thank Pete Malabuyoc for technical assistance and F. de Bruijn (Michigan State University, East Lansing) and Peter Young
(University of York, United Kingdom) for providing valuable suggestions.

\section{REFERENCES}

1. Alazard, D. 1985. Stem and root nodulation in Aeschynomene spp. Appl. Environ. Microbiol. 50:732-734.

2. Alazard, D. 1990 . Nitrogen fixation in pure culture by rhizobia isolated from stem nodules of tropical Aeschynomene species. FEMS Microbiol. Lett. 68:177-182.

3. Chakrabarti, S. K., A. K. Mishra, and P. K. Chakrabartty. 1986. A note on physiological characteristics and genetic relatedness of a fast-growing Rhizobium from stem nodule of Aeschynomene aspera L. J. Appl. Bacteriol. 60:463-468.

4. Eaglesham, A. R. J., J. M. Ellis, W. R. Evans, D. E. Fleischman, M. Hungaria, and R. W. F. Hardy. 1990. The first photosyn thetic $\mathrm{N}_{2}$-fixing Rhizobium: characteristics, p. 805-811. In P. M. Greshoff, L. E. Roth, G. Stacey, and W. L. Newton (ed.), Nitrogen fixation: achievements and objectives. Chapman and Hall, Ltd., London.

5. Evans, W. R., D. E. Fleischman, H. E. Calvert, P. V. Pyati, G. M. Alter, and S. Subba Rao. 1990. Bacteriochlorophyll and photosynthetic reaction centers in Rhizobium sp. strain BTAi 1. Appl. Environ. Microbiol. 56:3445-3449.

6. Graham, P. H., M. J. Sadowsky, H. H. Keyser, Y. M. Barnet, R. S. Bradley, J. E. Cooper, D. J. De Ley, B. D. W. Jarvis, E. B. Roslycky, B. W. Strijdom, and J. P. W. Young. 1991. Proposed minimal standards for the description of new genera and species of root- and stem-nodulating bacteria. Int. J. Syst. Bacteriol. 41:582-587.

7. Harashima, K., T. Shiba, T. Totsuka, U. Simidu, and N. Taga. 1978. Occurrence of bacteriochlorophyll $a$ in a strain of an aerobic heterotrophic bacteria. Agric. Biol. Chem. 40:16271628.

8. Hennecke, H., K. Kaluza, B. Thony, M. Furhmann, W. Ludwig, and E. Stackebrandt. 1990. Concurrent evolution of nitrogenase genes and 16S rRNA in Rhizobium species and other nitrogenfixing bacteria. Arch. Microbiol. 142:342-348.

9. Hollis, A. B., W. E. Kloos, and G. H. Elkan. 1981. DNA:DNA hybridization studies of Rhizobium japonicum and related Rhizobiaceae. J. Gen. Microbiol. 123:215-222.

10. Jarvis, B. D. W., M. Gillis, and J. De Ley. 1986. Intra- and intergeneric similarities between rRNA cistrons of Rhizobium and Bradyrhizobium species and some related bacteria. Int. J. Syst. Bacteriol. 36:129-138.

11. Jordan, D. C. 1984. Family III. Rhizobiaceae Conn 1938, p 234-254. In N. R. Kreig and J. G. Holt (ed.), Bergey's manual of systematic bacteriology, vol. 1. The Williams and Wilkins Co., Baltimore.

12. Kuykendall, L. D., B. Saxena, T. E. Devine, and S. E. Udell. 1992. Genetic diversity in Bradyrhizobium japonicum Jordan 1982 and a proposal for Bradyrhizobium elkanii sp. nov. Can. J. Microbiol. 38:501-505.

13. Ladha, J. K., R. P. Pareek, and M. Becker. 1992. Stemnodulating legume Rhizobium symbiosis and its agronomic use in lowland rice, p. 147-192. In B. A. Stewart (ed.), Advances in soil science, vol. 20. Springer-Verlag, New York.

14. Ladha, J. K., R. P. Pareek, R. B. So, and M. Becker. 1990. Stem nodule symbiosis and its unusual properties, p. 633-640. In P. M. Greshshoff, L. E. Roth, G. Stacey, and W. L. Newton (ed.), Nitrogen fixation: achievements and objectives. Chapman and Hall, Ltd., London.

15. Moore, W. E. C., and L. V. H. Moore. 1992. Index of the bacterial and yeast nomenclatural changes. American Society for Microbiology, Washington, D.C.

16. Sato, K. 1978. Bacteriochlorophyll formation by facultative methylotrophs, Protaminobacter and Pseudomonas AM1. FEBS Lett. 85:207-210.

17. Scholla, M. H., J. A. Moorfield, and G. H. Elkan. 1990. DNA homology between species of the rhizobia. Syst. Appl. Microbiol. 13:288-294.

18. Smibert, R. M., and N. Krieg. 1981. Systematics: general characterization, p. 409-443. In P. Gerhardt, R. G. E. Murray, R. N. Costilow, E. W. Nester, W. A. Wood, N. R. Krieg, and 
G. B. Phillips (ed.), Manual of methods for general bacteriology. American Society for Microbiology, Washington, D.C.

19. Sneath, P. A., and R. Sokal. 1973. Principles of numerical taxonomy. W. H. Freeman and Co., San Francisco.

20. So, R. B., J. K. Ladha, and J. P. W. Young. Submitted for publication.

21. Stanley, J., G. G. Brown, and D. P. S. Verma. 1985. Slowgrowing Rhizobium japonicum comprises two highly divergent symbiotic types. J. Bacteriol. 163:148-154.

22. Stowers, M. D., and A. R. J. Eaglesham. 1983. A stem-nodulating Rhizobium with physiological characteristics of both fast and slow-growers. J. Gen. Microbiol. 129:3651-3655.

22a.Urakami, T., and K. Komagata. 1984. Protomonas, a new genus of facultatively methylotrophic bacteria. Int. J. Syst. Bacteriol. 34:188-201.

22b.Van Niel, C. B. 1949. The cultural, general physiology, morphology, and classification of the non-sulfur and brown bacteria. Bacteriol. Rev. 5:1-118.

23. Vincent, J. M. 1970. A manual for the practical study of root nodule bacteria. IBP Handbook No. 15. Blackwell Scientific Publications, Oxford.

24. Watanabe, I., R. B. So, J. K. Ladha, Y. Fujimura, and $\mathbf{H}$. Kuraishi. 1987. A new nitrogen-fixing species of pseudomonad: Pseudomonas diazotrophicus sp. nov. isolated from the root of wetland rice. Can. J. Microbiol. 33:670-678.

25. Wishart, D. 1987. Clustan user's manual, 4th ed. University of St. Andrews, Edinburgh.

26. Woese, C. R. 1987. Bacterial evolution. Microbiol. Rev. 51:221271.

27. Woese, C. R., E. Stackebrandt, W. G. Weisburg, B. J. Paster, M. T. Madigan, V. J. Fowler, C. M. Hahn, P. Blanz, R. Gupta, K. H. Nealson, and G. E. Fox. 1984. The phylogeny of purple bacteria: the alpha subdivision. Syst. Appl. Microbiol. 5:315326.

28. Young, J. P. W., H. L. Downer, and B. D. Eardly. 1991. Phylogeny of the phototrophic rhizobium strain BTAi 1 by polymerase chain reaction-based sequencing of a 16S rRNA gene segment. J. Bacteriol. 173:2271-2277. 